\title{
EKSPLORASI KEGIATAN PRAKTIKUM IPA PGMI SELAMA PANDEMI COVID-19
}

\author{
Dita Purwinda Anggrella ${ }^{1}$, Amining Rahmasiwi ${ }^{2}$, Dwi Purbowati ${ }^{3}$ \\ Pendidikan Guru Madrasah Ibtidaiyah, IAIN Surakarta ${ }^{1,2,3}$ \\ Email: dita.anggrella@iain-surakarta.ac.id
}

\begin{abstract}
Abstrak
Penelitian ini bertujuan untuk mengeksplorasi pengalaman mahasiswa dalam melaksanakan kegiatan praktikum IPA selama pembelajaran daring ketika pandemi Covid-19. Penelitian ini merupakan penelitian eksploratif yang dianalisis secara deskriptif kualitatif. Populasi penelitian merupakan mahasiswa IAIN Surakarta. Teknik pengambilan sampel melalui purposive sampling, dimana partisipan yang terlibat dalam penelitian ini yaitu 80 mahasiswa PGMI IAIN Surakarta yang menempuh pembelajaran IPA pada saat pandemi Covid-19 yang dilaksanakan pada bulan Agustus 2020. Data penelitian diambil melalui penyebaran kuesioner online menggunakan platform google form dan wawancara terhadap dosen pengampu matakuliah. Hasil penelitian menunjukkan bahwa kegiatan praktikum IPA selama pandemi Covid-19 dilakukan melalui praktek secara mandiri di rumah dan direkam dalam bentuk video. Hasil penelitian menunjukkan bahwa 87,3\% mahasiswa menyatakan perkuliahan pada pembelajaran IPA selama pandemi kurang efektif karena kurangnya inovasi dosen dalam memilih strategi pembelajaran yang tepat untuk kegiatan praktikum, 61,9\% mahasiswa menyatakan kurangnya sumber belajar termasuk kesediaan alat dan bahan, serta 36,4\% mahasiswa menyatakan kurangnya referensi yang digunakan karena hanya memanfaatkan artikel jurnal dan laman internet. Penelitian ini juga menunjukkan temuan lain terkait kebutuhan sumber belajar praktikum bagi mahasiswa, dimana 50,8\% menyatakan butuh media elektronik, 33,9\% perlu modul, dan 7,6\% membutuhkan buku teks sebagai sumber belajar untuk praktikum.
\end{abstract}

Kata Kunci : Eksplorasi, Pandemi COVID-19, Praktikum IPA

\begin{abstract}
This study aims to explore student experiences in carrying out science practicum activities during online learning in covid-19 pandemic. This research is an exploratory research which analyzed in desriptive qualitative. The research population was the students of IAIN Surakarta. The sampling technique was purposive sampling, where the participants involved in this study were 80 students of PGMI IAIN Surakarta who studied science during the covid-19 pandemic in August 2020. Research data was taken through the distribution of online questionnaires using google form platform and interviews with lecturer. The results showed that science practicum activities during the COVID-19 pandemic were carried out through independent practice at home and recorded in video. The results showed $87.3 \%$ of students stated that the learning science process during the pandemic was ineffective due to the lack of lecturers' innovation in choosing appropriate learning strategies for practicum activities, $61.9 \%$ of students stated that there was a lack of learning resources including the availability of tools and materials, and $36.4 \%$ of students stated the lack of references used because they only had journal articles and internet pages. This study also discovered other findings related to the need for practicum learning resources for students, where 50.8\% said they needed electronic media, 33.9\% needed modules, and 7.6\% needed textbooks as learning resources for practicum.
\end{abstract}

Key Words : Exploration, Pandemic COVID-19, Science Practicum

\section{PENDAHULUAN}

Pandemi Covid-19 menyebabkan dampak dari berbagai sektor, termasuk pada dunia pendidikan, sehingga memaksa Pemerintah Indonesia melalui Kementerian Pendidikan dan Kebudayaan untuk menerapkan kebijakan pembelajaran jarak jauh, yaitu pemindahan ruang kelas konvensional ke ruang kelas online [1]. Hasil penelitian menunjukkan bahwa sebagian besar mahasiswa memiliki perspektif negatif terhadap pembelajaran online [2]. 
Meskipun mayoritas mahasiswa bersepakat bahwa pembelajaran online adalah solusi yang tepat selama pandemi Covid-19. Namun pembelajaran online yang dilaksanakan tanpa perencanaan yang matang mengakibatkan tidak adanya kemudahan, keterlibatan, dan efektivitas pembelajaran online. Terlebih pembelajaran secara online berpengaruh terhadap pemahaman mahasiswa terhadap materi matakuliah yang dirasa tidak maksimal [3].

Dampak ini semakin dirasakan pada matakuliah yang terdapat praktikum dalam pelaksanaan pembelajarannya [3]. Salah satu matakuliah yang harus menerapkan praktikum, yaitu pembelajaran IPA atau sains. Pembelajaran sains merupakan pembelajaran yang menjelaskan mengenai kehidupan dan alam yang ada di sekitar serta permasalahan yang harus dicari solusinya [4], sehingga dalam pembelajaran sains harus ada kegiatan ilmiah (science activities), agar pembelajaran menjadi lebih bermakna dan mudah dipahami, serta melatih keterampilan saintifik mahasiswa.

Sains sendiri termasuk salah satu mata pelajaran yang memiliki konsep yang sulit untuk dipahami dan dipelajari [5], ditambah lagi menurut penelitian bahwa keadaan pandemi Covid-19 menyebabkan pembelajaran sains menjadi tidak efektif karena kurangnya buku atau referensi yang bisa menjadi pegangan untuk mahasiswa dalam menyusun laporan praktikum [3], hal ini berdampak pada tidak tercapainya Capaian Pembelajaran (CP) dan keterampilan sains abad-21.

Praktikum IPA memiliki peran yang sangat penting dalam pembelajaran sains karena dapat mengembangkan sikap ilmiah dan keterampilan proses sains [6] dan literasi sains peserta didik serta pengembangan sikap ilmiah [7], memperkuat pemahaman peserta didik, melatih keterampilan proses sains, berpikir rasional, dan procedural [8].

Melihat pentingnya peran praktikum untuk pembelajaran sains, menyebabkan peran praktikum harus tetap dilakukan meski dalam keadaan pandemi. Selama masa pandemi, kegiatan praktikum IPA mengalami banyak perubahan. Namun tidak semua pendidik menerapkan strategi pembelajaran secara efektif pada kegiatan praktikum. Penelitian sebelumnya telah melakukan eksplorasi terkait efektivitas kegiatan praktikum selama pandemi Covid-19, hasil penelitian menunjukkan praktikum yang dilakukan secara daring selama pandemi Covid-19 tidak efektif, hal ini disebabkan karena kendala utamanya adalah alat dan bahan praktikum [9].

Berdasarkan uraian di atas, terkait urgensi pelaksanaan praktikum matakuliah sains/IPA, maka peneliti memandang penting untuk dilakukannya eksplorasi lebih jauh terkait efektivitas kegiatan praktikum di masa pandemi, dimana tujuan dari penelitian ini adalah untuk mengeksplorasi pelaksanaan kegiatan praktikum mahasiswa saat pandemi Covid 19, yang mencakup kendala yang dihadapi mahasiswa, sumber belajar yang digunakan, teknik yang digunakan dosen ketika pembelajaran IPA, dan efektivitas kegiatan praktikum dalam keadaan pandemi Covid-19, dimana hasil dari penelitian ini berkontribusi untuk perbaikan pembelajaran IPA terutama pada kegiatan praktikum ketika dilakukan secara daring.

\section{METODE}

Penelitian ini merupakan penelitian eksploratif dan dianalisis secara deskriptif kualitatif. Teknik pengambilan sampel menggunakan purposive sampling, dimana sampel yang terlibat dalam penelitian berdasarkan karakteristik yang telah ditentukan peneliti yaitu mahasiswa 
program studi PGMI IAIN Surakarta yang telah menempuh matakuliah pembelajaran IPA melalui pembelajaran daring ketika pandemi Covid-19. Teknik pengumpulan data melalui wawancara kepada dosen pengampu matakuliah IPA PGMI, dan penyebaran angket kepada 80 mahasiswa berupa kendala dalam pelaksanaan praktikum, sumber belajar yang digunakan, kegiatan pembelajaran yang dilakukan selama pembelajaran, dan efektivitas pelaksanaan praktikum. Pengambilan data dilakukan pada bulan Agustus 2020 melalui Google Form. Instrumen angket yang digunakan merupakan modifikasi dari angket [10] yang telah teruji validitasnya secara isi maupun konstruk.

\section{HASIL DAN PEMBAHASAN}

Semenjak adanya pandemi Covid-19, semua satuan pendidikan terutama yang berada di zona merah telah dihimbau oleh Pemerintah untuk melakukan kegiatan pembelajaran secara online, tak terkecuali PTKIN IAIN Surakarta. Selama pelaksanaan perkulihan secara online, banyak sekali kendala dan kekurangan yang dihadapi baik mahasiswa maupun dosen. Salah satu matakuliah yang terkena dampak dari pembelajaran secara online ini adalah pembelajaran IPA di PGMI. Hal ini dikarenakan pembelajaran IPA memiliki praktikum dalam pelaksanaannya. Kegiatan praktikum memiliki peranan yang sangat penting terutama dalam pembelajaran IPA, hal ini disebabkan untuk memahami sebuah konsep, mahasiswa harus melakukan pembuktian secara ilmiahnya [11], selain itu praktikum juga dapat mengasah keterampilan ilmiah [12] dan membuat mahasiswa tidak merasa jenuh dalam pembelajaran [13], sehingga kegiatan praktikum harus tetap dilakukan meskipun dalam keadaan pandemi melalui pembelajaran secara daring. Hasil dari studi eksplorasi pembelajaran praktikum IPA PGMI selama pandemi Covid-19 dijabarkan sebagai berikut:

\section{Kendala Pelaksanaan Praktikum}

Pembelajaran jarak jauh ketika pandemi memaksa perkuliahan IPA tidak dapat dilakukan di laboratorium, sedangkan laboratorium memainkan peranan yang sangat penting untuk memfasilitasi mahasiswa dalam pemahaman proses sains dan memahami konsep sains, karena konsep sains harus dipelajari melalui proses penyelidikan, bukan hanya menghafal suatu teori. Kendala kegiatan praktikum selama pandemi disebabkan karena menurut $61,9 \%$ mahasiswa merasa kurangnya kesediaan alat dan bahan praktikum, serta $36,4 \%$ mahasiswa menyatakan karena kurangnya referensi yang digunakan seperti bahan ajar.

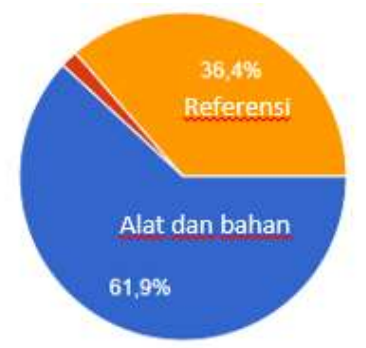

\section{Gambar 1. Kendala Pelaksanaan Praktikum Selama Pandemi}

Keberadaan alat dan bahan merupakan faktor yang harus tersedia dalam kegiatan praktikum, apabila ketersediaan alat dan bahan praktikum tidak terakomodasi maka kegiatan praktikum tidak akan berjalan lancar dan akan berdampak pada pemahaman konsep mahasiswa. Selama pandemi, mahasiswa harus mencari alat dan bahan sendiri agar kegiatan praktikum tetap berjalan. Berdasarkan hasil wawancara dengan dosen pengampu matakuliah, alat dan bahan praktikum yang digunakan oleh mahasiswa diperoleh dari bahan daur ulang atau bahan yang sudah tidak terpakai dan mudah didapat di rumah untuk mempermudah mahasiswa agar kegiatan praktikum tetap berjalan. Pernyataan tersebut sejalan dengan penelitian yang menunjukkan ketersediaan alat dan bahan yang mudah didapat dari 
rumah, akan memudahkan keterlaksanaan praktikum [9].

Penggunaan bahan daur ulang pada kegiatan praktikum juga didukung oleh penelitian sebelumnya bahwa agar pembelajaran IPA/sains tetap berjalan selama pembelajaran jarak jauh adalah dengan memanfaatkan barang daur ulang yang dapat dimanfaatkan dalam kegiatan praktikum [14]. Bahan daur ulang adalah istilah yang digunakan untuk memperoleh bahan dan perlengkapan dari lingkungan siswa dengan menggunakan barang bekas atau home materials menjadi barang atau produk baru yang bermanfaat untuk kegiatan praktikum dalam peningkatan keterampilan proses sains siswa.

Namun, berdasarkan hasil angket penggunaan alat dan bahan daur ulang ternyata masih dianggap kendala oleh mahasiswa pada pembelajaran daring ketika pandemi Covid-19. Hal ini diperjelas oleh pernyataan dosen pengampu matakuliah, kendala ketersediaan alat dan bahan praktikum saat pembelajaran daring disebabkan masih belum terbiasanya mahasiswa dalam menggunakan alat dan bahan dari bahan daur ulang, karena mahasiswa sudah terbiasa menggunakan alat dan bahan praktikum yang sudah tersedia di laboratorium, selain itu dibutuhkan kreativitas yang tinggi dalam menggunakan alat dan bahan daur ulang.

\section{Sumber Belajar/Referensi}

Sumber belajar merupakan hal paling penting dalam mendukung proses pembelajaran. Berdasarkan hasil angket pada aspek kendala kegiatan praktikum, $36,4 \%$ mahasiswa menyatakan referensi merupakan salah satu kendala dalam pembelajaran IPA. Selama ini sumber belajar dan referensi yang digunakan oleh mahasiswa dalam mendukung pembelajaran IPA menurut $30,5 \%$ mahasiswa adalah buku teks, dan 50\% mahasiswa menyatakan jurnal penelitian dan lainnya.

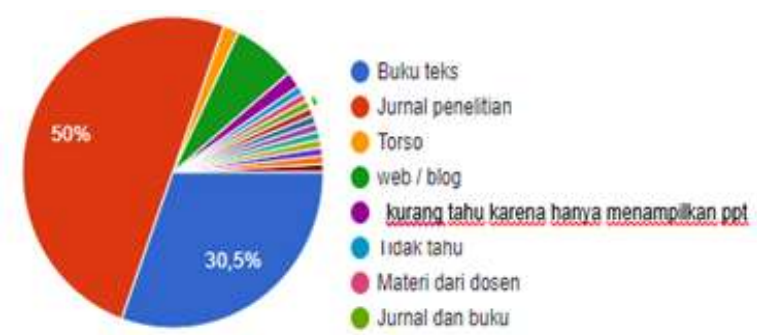

Gambar 2. Sumber Belajar IPA

Berdasarkan hasil wawancara dengan dosen pengampu matakuliah IPA, selama ini pembelajaran IPA belum memiliki sumber belajar seperti modul dan buku pegangan. Referensi yang digunakan menurut dosen pengampu matakuliah adalah berupa artikel jurnal dan laman internet. Setiap kali pertemuan perkuliahan dosen pengampu memberikan Lembar Kerja Mahasiswa (LKM) yang berisikan petunjuk praktikum. Tidak heran kurangnya sumber belajar menjadi kendala bagi mahasiswa dalam pembelajaran IPA terutama pada kegiatan praktikum. Hal ini didukung penelitian yang menjelaskan bahwa selama pandemi Covid-19 kegiatan praktikum semakin tidak efektif, karena kurangnya buku/referensi mahasiswa dalam menyusun laporan praktikum [15].

Dosen pengampu matakuliah menyarankan, mahasiswa membutuhkan suatu sumber belajar yang tidak hanya berupa petunjuk praktikum, tetapi juga sumber belajar yang dapat diintegrasikan dengan mengembangkan keterampilan abad 21 mahasiswa, serta dapat diakses dimanapun, sehingga kegiatan belajar mengajar menjadi lebih fleksibel. Hal ini didukung berdasarkan hasil angket mahasiswa akan kebutuhan sumber belajar, $50,8 \%$ mahasiswa menyatakan membutuhkan sumber belajar berupa media elektronik, 33,9\% mahasiswa menyatakan modul, dan 7,6\% buku teks. 

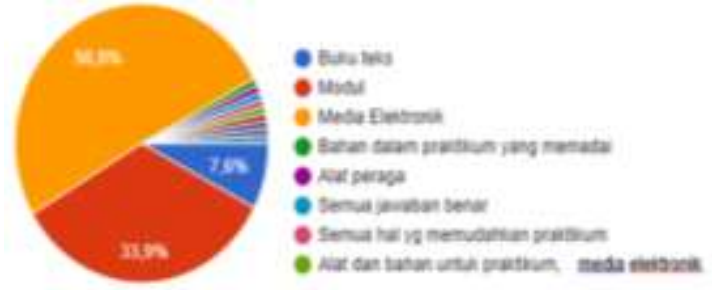

Gambar 3. Sumber Belajar yang Dibutuhkan Mahasiswa

Berdasarkan permasalahan yang dihadapi oleh prodi PGMI pada matakuliah IPA, menunjukkan perlunya kebutuhan akan sumber belajar berupa modul elektronik $(e-$ modul) pada matakuliah IPA PGMI. Salah satu sumber belajar yang cocok digunakan oleh mahasiswa PGMI IAIN Surakarta adalah berupa modul elektronik (e-modul). Hal ini mempertimbangkan dari pembelajaran yang dilakukan secara online di masa pandemi, juga karena e-modul akan lebih praktis dan fleksibel penggunaannya. E-modul merupakan bahan ajar dengan memanfaatkan sarana elektronik [16]. Penelitian menyatakan bahwa e-modul lebih meningkatkan minat, dan motivasi karena tampilan dari e-modul lebih menarik [17]. Keberadaan e-modul saja dipandang tidak cukup sebagai pegangan mahasiswa, modul harus dapat diintegrasikan dengan pendekatan yang dapat memberdayakan keterampilan abad 21 yaitu dengan pendekatan saintifik. 98,3\% setuju untuk dikembangkannya bahan ajar dengan pendekatan saintifik.

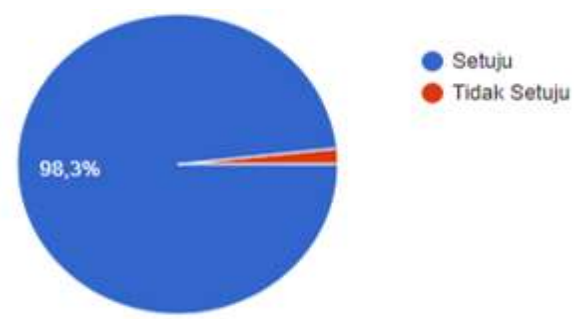

Gambar 4. Kebutuhan Bahan Ajar $E$ -
Modul dengan Pendekatan Saintifik

Berdasarkan penelitian, salah satu pendekatan alternatif yang berpotensi dalam membangun keterampilan abad 21 adalah STEM (Science, Technology,
Engineering and Mathematics) [18]. STEM merupakan salah satu pendekatan pembelajaran yang cocok diterapkan pada mahasiswa PGMI, karena menghubungkan antara sains, teknologi, engineering, dan matematika. Manfaat STEM di antaranya dapat membantu mahasiswa dalam memecahkan masalah menjadi lebih inovatif, berpikir logis, dan mandiri [19]. Pembelajaran dengan pendekatan STEM juga cocok diterapkan secara online karena merupakan pembelajaran kontekstual yang mengajak mahasiswa memahami fenomena-fenomena di sekitar lingkungannya [20].

\section{Teknik Pembelajaran IPA}

Teknik pembelajaran yang pernah diterapkan oleh dosen pengampu matakuliah pada pembelajran IPA yakni presentasi, diskusi kelompok dan praktikum. Pernyataan tersebut didukung berdasarkan hasil angket mahasiswa, teknik pembelajaran ketika pandemi Covid-19 yang dilakukan selama pembelajaran IPA ditunjukkan pada diagram di bawah:


Gambar 5. Teknik Pembelajaran IPA

Terlihat bahwa 19,5 \% mahasiswa menjawab diskusi kelompok, 39\% presentasi, dan $13,6 \%$ melalui praktikum. Dari hasil angket tersebut dapat ditarik kesimpulan bahwasanya selama pembelajaran IPA, kegiatan praktikum memiliki porsi yang sedikit, sebagian besar pembelajaran IPA menggunakan teknik presentasi dalam proses pembelajarannya. Hal ini menyebabkan kurangnya kebebasan mahasiswa dalam bereksperimen atau bersikap ilmiah. 
Sikap ilmiah penting dalam pembelajaran sains, karena dalam sains tidak hanya mementingkan kognitif mahasiswa, tetapi juga aspek afektif untuk melatih keterampilan abad 21 mahasiswa. Keterampilan abad 21 dapat diberdayakan melalui model pembelajaran saintifik [21]. Model pembelajaran saintifik yang pernah diterapkan pada matakuliah IPA selama ini adalah Project Based Learning (PjBL). Namun, dosen pengampu matakuliah belum pernah mengukur kemampuan keterampilan abad 21 mahasiswa dalam perkuliahan IPA. Dari sini dapat disimpulkan, bahwa kurangnya inovasi dosen pengampu matakuliah dalam memilih strategi pembelajaran karena kurang siapnya dosen pada pembelajaran jarak jauh ketika harus menerapkan praktikum pada pembelajaran IPA.

\section{Efektivitas Kegiatan Praktikum IPA}

Perhatikan gambar berikut.



\section{Gambar 6. Efektivitas Praktikum Selama Pandemi}

Berdasarkan hasil wawancara dengan dosen pengampu matakuliah, kegiatan praktikum selama pandemi dilakukan dengan memberikan tugas kepada mahasiswa untuk mempraktikkan kegiatan praktikum di rumah masing-masing dan direkam dalam bentuk video. Hal ini dikarenakan tidak memungkinkan kegiatan praktikum dilakukan secara luring untuk mencegah penyebaran Covid-19. Berdasarkan hasil angket mahasiswa, mayoritas $87,3 \%$ mahasiswa menyatakan kegiatan praktikum selama pandemi
Covid-19 yang dilakukan dengan cara direkam dalam bentuk video pada pembelajaran IPA tidak efektif.

Hasil angket ini didukung berdasarkan aspek sebelumnya, seperti kurangnya alat bahan praktikum dan belum terbiasanya atau kurangnya kesiapan mahasiswa melakukan kegiatan praktikum secara daring. Kurangnya referensi dalam mendukung kegiatan praktikum dan pemahaman konsep. Kurangnya inovasi dosen pengampu matakuliah dalam memilih strategi pembelajaran selama pembelajaran jarak jauh, hal ini dikarenakan kurang siapnya dosen dalam pembelajaran jarak jauh. Hal ini diperjelas dari penelitian yang menyatakan faktor yang mendukung pelaksanaan praktikum selama pembelajaran jarak jauh adalah kesiapan dari pendidik maupun peserta didik, alat dan bahan praktikum, dan pemanfaatan bahan ajar [9].

Banyaknya kelemahan dalam pembelajaran secara daring menimbulkan dampak terhadap hasil belajar mahasiswa, dimana hasil belajar IPA pada saat pembelajaran secara daring lebih rendah daripada ketika pembelajaran secara luring [22]. Hasil penelitian juga menunjukkan bahwa praktikum secara luring lebih efektif daripada praktikum yang dilakukan secara daring [23]. Lebih lanjut, berdasarkan penelitian bahwa kegiatan praktikum pada pembelajaran jarak jauh lebih efektif menggunakan laboratorium virtual (Virtual Labs) [24].

\section{SIMPULAN}

Berdasarkan hasil dan pembahasan dapat disimpulkan bahwa kegiatan praktikum IPA PGMI selama pandemi Covid-19 terdapat beberapa kendala yang dihadapi mahasiswa seperti: (1) kurangnya ketersediaan alat dan bahan praktikum; (2) kurangnya sumber belajar seperti bahan ajar sebagai penunjang pembelajaran IPA; 
(3) teknik pengajaran yang kurang adanya inovasi dosen dalam memilih strategi pembelajaran pada pembelajaran IPA, sehingga menyebabkan kegiatan praktikum selama pandemi Covid-19 menjadi tidak efektif.

\section{DAFTAR PUSTAKA}

[1] Keputusan Menteri Pendidikan dan Kebudayaan No. 4 Tahun 2020. "Pelaksanaan Kebijakan Pendidikan dalam Masa Darurat Penyebaran Coronavirus Disease (Covid-19)". Surat Edaran dari Kementrian RI, 2020, [Online]. Tersedia: https://pusdiklat.kemdikbud.go.id/sur at-edaran-mendikbud-no-4-tahun2020-tentang-pelaksanaan-kebijakanpendidikan-dalam-masa-daruratpenyebaran-corona-virus-diseasecovid-1-9/ [Diakses Tanggal 31 Mei 2021]

[2] M. Rohman, D. A. Sudjimat, R. M. Sugandi, and D. Nurhadi, "Online Learning in Higher Education During Covid-19 Pandemic: Students' Perceptions," Talent Dev. Excell., vol. 12, no. 2s, pp. 3644-3651, 2020.

[3] D. Hariyanti, A. H. Mun'im, dan N. Hidayat, "Identifikasi Hambatan Mahasiswa dalam Pelaksanaan Pembelajaran Biologi secara Daring Selama Pandemi Covid-19 di Kabupaten Jember," ALVEOLI J. Pendidik. Biol., vol. 1, no. 1, pp. 1121, 2020.

[4] A. Permanasari, "Kurikulum 2013: Implikasi dalam Pembelajaran di Sekolah, Pendidikan Profesi dan Pendidikan Tinggi," in Prosiding Seminar Nasional, vol. 01, no. 1, pp. 6-16, 2014.

[5] E. Buah and A. F. Akuffo, "The Science Topics Perceived Difficult by Junior High School Students at Techiman North District: Effects on the Teaching and Learning of Science," Imp. J. Interdiscip. Res., vol. 3, no. 1, pp. 503-509, 2017.

[6] Y. Suryaningsih, "Pembelajaran Berbasis Praktikum sebagai Sarana Siswa untuk Berlatih Menerapkan Keterampilan Proses Sains dalam Materi Biologi," Bio Educ., vol. 2, no. 2, pp. 49-57, 2017.

[7] D. Daniah, "Pentingnya Inkuiri Iilmiah pada Praktikum dalam Pembelajaran IPA untuk Peningkatan Literasi Sains Mahasiswa," PIONIR J. Pendidik., vol. 9, no. 1, pp. 114153, 2020.

[8] I. C. Gilang, Mujasam, W. Sri rahayu, dan Yusuf, "Efektivitas Pemanfaatan Laboratorium IPA dalam Pembelajaran Fisika di SMA Yapis Manokwari," in In Prosiding Universitas Cokroaminoto Palopo, 2018, vol. 03, no. 1, pp. 166-176.

[9] T. Sholikah, et al., "Studi Eksplorasi Kegiatan Praktikum Sains saat Pandemi Covid-19," Indones. J. Sci. Learn., vol. 1, no. 2, pp. 67-75, 2020.

[10] D. P. Anggrella, S. E. Indriwati, dan S. R. Lestari, "Analisis Kebutuhan Sumber Belajar Matakuliah Anatomi Fisiologi Manusia Berdasarkan Model Pengembangan Analyze Design Develop Implement Evaluation," J. Pendidik. Teor. Penelitian, dan Pengemb., vol. 5, no. 8, pp. 1066-1071, 2020.

[11] T. Winarti dan S. Nurhayati, "Pembelajaran Praktikum Berorientasi Proyek untuk Meningkatkan Keterampilan Proses Sains dan Pemahaman Konsep," $J$. Inov. Pendidik. Kim., vol. 8, no. 2, pp. 1409-1419, 2015.

[12] M. S. Hayat, S. Anggraeni, dan S. Redjeki, "Pembelajaran Berbasis Praktikum pada Konsep Invertebrata untuk Pengembangan Sikap Ilmiah Siswa," Bioma, vol. 1, no. 2, pp. 141-152, 2011.

[13] F. Rizkiana, I. W. Dasna, dan S. 
Marfu'ah, "Pengaruh Praktikum dan Demonstrasi dalam Pembelajaran Inkuiri Terbimbing terhadap Motivasi Belajar Siswa Materi Asam Basa Ditinjau dari Kemampuan Awal," J. Pendidik. Teor. Penelitian, dan Pengemb., vol. 1, no. 3, pp. 354362, 2016.

[14] S. Prajoko, M. Amin, F. Rohman, and M. Gipayana, "The Usage of Recycle Materials for Science Practicum: Is There Any Effect on Science Process Skills?," Int. J. Eval. Res. Educ., vol. 6, no. 1, pp. 1-8, 2017.

[15] D. Hariyanti, A. Haq, dan N. Hidayat, "Identifikasi Hambatan Mahasiswa dalam Pelaksanaan Pembelajaran Biologi secara Daring Selama Pandemi Covid-19 di Kabupaten Jember," ALVEOLI J. Pendidik. Biol., vol. 1, no. 1, pp. 1121, 2020.

[16] N. N. A. Udayana, I. M. A. Wirawan, dan D. G. H. Divayana, "Pemrograman Berorientasi Objek dengan Model Pembelajaran Project Based Learning Kelas XII Rekayasa Perangkat Lunak," J. Nas. Pendidik. Tek. Inform., vol. 6, no. 2, pp. 128139, 2017.

[17] Syahrial, Asrial, D. A. Kurniawan, dan S. O. Piyana, "E-Modul Etnokontruktivisme: Implementasi pada Kelas V Sekolah Dasar Ditinjau dari Persepsi, Minat dan Motivasi," JTP - J. Teknol. Pendidik., vol. 21, no. 1, pp. 165-177, 2019.

[18] A. Permanasari, "STEM Education: Inovasi dalam Pembelajaran Sains," in In Prosiding SNPS (Seminar Nasional Pendidikan Sains), pp. 2334, 2016.

[19] M. Stohlmann, T. Moore, and G.
Roehrig, "Considerations for Teaching Integrated STEM Education," J. Pre-College Eng. Educ. Res., vol. 2, no. 1, pp. 28-34, 2012

[20] G. Yakman and H. Lee, "Exploring the Exemplary STEAM Education in the U.S. as a Practical Educational Framework for Korea," $J$ Korea Assoc. Sci. Edu, vol. 32, no. 6, pp. 1072-1086, 2012.

[21] A. R. Setiawan, "Penerapan Pendekatan Saintifik dalam Pembelajaran Biologi sebagai Upaya Melatih Literasi Saintifik Siswa Sekolah Menengah," in Prosiding Seminar Nasional Biologi "Inovasi Penelitian dan Pendidikan Biologi III (IP2B III) 2019”, no. Ip2b Iii, pp. 140-145, 2019.

[22] P. Soraya, C. E. Putri, P. A. Lestari, dan A. Walid, "Profil Penilaian Hasil Belajar IPA Melalui Media Daring dan Luring pada Mid Semester di MTS Negeri 4 Mukomuko Provinsi Bengkulu," J. Sikola J. Kaji. Pendidik. dan Pembelajaran, vol. 2, no. 2, pp. 107-115, 2020.

[23] R. Astuti, G. M. Setianingsih, dan S. Rahayu, "Efektivitas Praktikum Biokimia secara Luring dan Daring Guna Meningkatkan Pemahaman Materi Protein pada Mahasiswa," $J$. Inov. dan Sains, vol. 2, no. 1, pp. 1318, 2021.

[24] I. Puspita, "PhET Aplication Program: Strategi Penguatan Pemahaman Pembelajaran Jarak Jauh pada Materi Radiasi Benda Hitam melalui Percobaan Berbantu Lab Virtual dan Media Sosial," $J$. Pendidik. Madrasah, vol. 5, no. 1, pp. 57-68, 2020. 